\title{
Transatlantica
}

Revue d'études américaines. American Studies Journal

\section{Voices in the Urban Wilderness: Reimagining the Terms of Order in "Renaissance" Boston}

Jeffrey Helgeson

\section{(2) OpenEdition}

Journals

Electronic version

URL: https://journals.openedition.org/transatlantica/16126

DOI: 10.4000/transatlantica.16126

ISSN: 1765-2766

\section{Publisher}

Association française d'Etudes Américaines (AFEA)

Electronic reference

Jeffrey Helgeson, "Voices in the Urban Wilderness: Reimagining the Terms of Order in "Renaissance" Boston", Transatlantica [Online], 2 | 2020, Online since 01 February 2021, connection on 10 February 2023. URL: http://journals.openedition.org/transatlantica/16126 ; DOI: https://doi.org/10.4000/ transatlantica. 16126

This text was automatically generated on 10 February 2023.

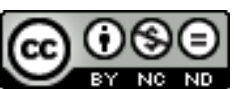

Creative Commons - Attribution-NonCommercial-NoDerivatives 4.0 International - CC BY-NC-ND 4.0 https://creativecommons.org/licenses/by-nc-nd/4.0/ 


\title{
Voices in the Urban Wilderness: Reimagining the Terms of Order in "Renaissance" Boston
}

\author{
Jeffrey Helgeson
}

\section{Introduction}

Out of the darkest years in their city's modern history, Bostonians achieved what has been described as a marvel of urban history. Suffering both chronic decline and an acute social and economic crisis in the 1960s and 1970s, Boston emerged in the succeeding decades as a leader amongst the nation's newly thriving technology- and professional-service-based urban economies. Beginning in the 1970s, reinvigorated corporate leadership gained increasing power over the city's reform and set the stage for a period that would become known as the "Boston Renaissance" (Bluestone and Stevenson). At the same time, however, in reviving Boston, the city's top-down reformers had created new inequalities and new forms of exploitation. Beginning in the late 1970s, corporate reformers also drew strength from, and fostered the influence of, a culture of individualistic consumer-oriented, competitive social values hostile to a deep, yet always contested, history of striving to realize the city's potential as a democratic commonwealth (Peterson). Boston became a central location not just for the rise of the power of finance and corporate leaders, not just for growing inequality, but also for the increasing influence of what political theorist Wendy Brown has referred to as "neoliberal rationality" (21).

2 Renaissance Boston must be understood, in part, as the product of efforts to market and implement for-profit services and a finance-oriented economy as a rejection of both the welfare state and the more egalitarian urban political economy envisioned by activists in the late 1960s. The effects of this project could be seen in the growing commitment to the creation of profit centers in everything from public schools, public universities, and public infrastructure to residential housing and artistic culture. More 
broadly, the implications were felt in an intensification of values emphasizing individuated market-based success over commitments to valorization of the common good.

The rise of an increasingly privatized and unequal Boston sparked diverse, if fragmented, resistance even as it was being born in the 1970s. ${ }^{1}$ In order to understand the history of that resistance, we need to appreciate that, for many Bostonians, much about life in the city remained the same under neoliberalism. For such residentsespecially those living in or on the edges of poverty in the city's African American, Latino, Caribbean, Cape Verdean, white ethnic, and gay and lesbian communities-the institutions of the postwar liberal city had delivered relatively few benefits. Many residents never experienced the security that came to define postwar liberalism for those with access to good blue-collar jobs, the benefits of the welfare state, or protections from violence at the hands of employers, neighbors, and the police. For them, the transformation of the city during and after the 1970s represented not so much the loss of an era of liberal opportunity, as the remaking of the city's structures and relations of inequality, segregation, exploitation, and violence.

This essay will focus on the work of two Bostonians in particular-writer and activist Fanny Howe and Black Power artist and activist, Dana Chandler, Jr. (Akin Duro)-who imagined and sought to create alternative futures for Boston beginning in the late 1960s. Their work challenged not just the fact of deepening inequality at the outset of an age of economic growth, but also the very terms of order that infused dominant notions of political and economic thinking. What Boston-based writer and activist Fanny Howe has described as "bewilderment as a poetics and a politics" (2003 5) or what Chandler conceived of as a people's art of survival in an intrinsically violent city provide an alternative way to approach late-twentieth-century Boston from the perspective of those who experience it as more an urban wilderness than a renaissance city.

Howe's and Chandler's critiques of Boston's renaissance called into question what was actually new about "neoliberal" Boston. Howe, deeply enmeshed in mutualistic networks of working women and tenant activism, in her essays and novels has insisted upon the importance of the politics of people alienated from the organizing principles of their time, yet who continued to circle around the problems of life. In her everyday life and activism, as much as in her writings, Howe draws attention to the ways that the struggle for life and meaning in the city ran up not against temporary crises, but against constantly renewed challenges to find one's way in the fundamentally disorienting urban wilds. Similarly, as both an activist and an artist, Chandler has highlighted the continuities of racist violence in the United States, as well as the effects of that violence on, and the responses to it from, African Americans in Boston and far beyond. Positioning himself simultaneously as a "people's artist" and as a civic leader seeking to carve out space for Black artists in an exclusive Boston artworld, it was the continuities of struggle and oppression across the liberal and neoliberal eras that predominated in Chandler's work, as well.

6 Howe and Chandler, in their own ways, intentionally disrupted linear understandings of historical time as either universal progress or shared disruption. The lessons of their work reinforce historian N.D.B. Connolly's argument that the concept of neoliberalism as it has been generally deployed is problematic because "the demise of the white social contract gets cast as universal” (Connolly). For Howe and Chandler, renaissance Boston 
had much more in common with previous eras of the city as an urban wilderness than such a universalistic conception of the neoliberal turn would allow.

7 Figures like Howe and Chandler helped to conceive, and attempted to act upon, the potentially disruptive mix of ideas of the late 1960s and 1970s. Dissidents from the individualistic, market-oriented, anti-egalitarian reordering of cities in crisis, they sought to work against the violence they saw as inherent to the order imposed upon the city. The exigencies of their own everyday struggles as activist artists, as well as their creative ambition, compelled them to imagine histories of those who had lived such resistance both to the challenges of their moment and to the terms of order of the modern city.

8 This is a history of political activism, emphasizing for the time being the ways political dissent took shape in the literary and visual arts. In part because they were fragmented, such dissents remained the province of outsider voices. They amounted to, to borrow a phrase from radical political scientist Cedric J. Robinson, "a perceptual and conceptual negation" of neoliberal values and culture, but "not a historical one" (202). Still, this is the kind of negation that holds the potential for broader connections or even solidarities. Robinson suggests the possibility for "a metaphysics of kinship [...] constantly referred to in the 'brotherhoods' and 'sisterhoods' which characterize the movements of oppressed peoples" in many different contexts (203). The bewildered offered important, if not entirely worked-out, visions of a city that would take seriously the kinds of violence being done to the commons. They cried out for their fellow Bostonians to be ready for a new way of ordering the city with a rich sense of the "social," with a commitment to a truly child-centered city, with an engagement in mutual self-defense against the predators in the urban wilderness, and with a recognition of what Robinson describes as the "incompleteness" and interwovenness of us all (196-203).

\section{The Predator State and the Boston Renaissance}

It all seemed so reasonable and responsible-a professionally-crafted treatment for the chaos afflicting Boston in the 1970s. The leaders of the city's resurgent finance and professional services industries would join in the push to revive the declining city. When Federal Judge W. Arthur Garrity issued the 1974 order to implement mandatory school desegregation in Boston, he had added a supplementary order calling for community groups to have input into desegregation. He intended to include parent groups, clergy, community organizations, and civic leaders, but corporations took up the call for a much broader and long-term effort to gain influence over the direction of the city's public institutions. Were they not members of the "community" of Boston? Had not the city been ailing from an aloof class of business leaders, unwilling or unable to confront the city's economic slide, much less its deepening social divisions? As important, had not the city been suffering from what Harvard political scientist Samuel Huntington famously described as an "excess of democracy"-too many protests, too many mobs, too many expectations for government aid (Crozier et al. 113)? Responsible corporate leadership would invest their immense wealth and managerial capacity in the reform of the city's schools and, while they were at it, the redevelopment of the neighborhoods around the schools. What some may now derogatorily call "neoliberal 
Boston" (Larson 96) was, in the minds of many at the time, merely the rise of commonsense solutions to the maladies afflicting a city in crisis.

Boston emerged as a national model for how to employ public-private collaborations to ameliorate urban problems. Insiders like Paul Grogan, the head of Boston's Neighborhood Development and Employment Agency under Mayors Kevin White and Ray Flynn, celebrated Boston's revival. The city made progress that came "against all odds and unforeseen," Grogan crowed in his introduction to a collection of essays on late-twentieth-century Boston, The Good City. "The truly wonderful thing" about renewal in Boston, Grogan continued, "is that it was engineered-by politicians, business leaders, and community activists who stubbornly refused to accept the apparent verdict of history on Boston" (4). Academics tended to see a bit more of a balance of success and failure, but overall, they touted the "Boston Renaissance." Harvard urban scholar Alexander Von Hoffman, for example, concluded:

in Boston, perhaps more than any other city, the community development movement took advantage of economic good times to shape an urban revival. Through years of trial and error, the city's nonprofit organizations and public agencies developed remarkable skills in collaboration [producing] spectacularly effective community development and anti-crime programs. (80)

In retrospect, however, it is clear, as it was clear to many at the time, that such collaborations remade rather than resolved the city's divides. When Boston's corporations formed the Boston Compact to work with the city's public schools to reform the curriculum and sponsor job training and placement programs, these critics saw the persistence of racial segregation, unequal schooling, rising drop-out rates, and declining enrollment and graduation rates (Farrar and Cipollone 7). For instance, national dropout rates had increased from 19.5 percent to 25 percent between 1972 and 1982. Boston's School Department officially acknowledged a 10 percent dropout rate, but "administrators privately admitted that the true figure was closer to $50 \%$ " (Farrar 2). Even as those who did manage to graduate and to find jobs through the collaborations, high school dropout rates actually increased during the 1980s from 33 percent in 1983 to 39 percent in 1985 and 40 percent in 1986 and 1987 (Cronin 191).

11 The increasingly privatized metropolitan school system also provided highly unequal educational opportunities, with the public school system a segregated resource for those who could not access, or were excluded from, the network of suburban or newly privatized city schools. By 1987, 60 percent of Boston Public Schools students lived in houses that received federal poverty aid. Three-quarters were from single-parent homes or foster homes, and nearly half lived in public housing (Farrar and Cipollone 7). By 1991, only 20 percent of Boston households had children in the city's public schools (Portz 2). And in the early 1990s, critics of the collaborations concluded that publicprivate collaborations in school reform had fed a larger project of privatization of the public schools, with new challenges for students unable to meet the standards of "excellence" (Dunphy and Perkins; Schneider).

The same private-sector leaders who pushed such problematic reforms in the schools, also led initiatives to redevelop the neighborhoods around the schools. They formed the Boston Housing Partnership in the early 1980s to bring community development organizations together with city officials to rehabilitate and build low-income housing. Yet critics saw mortgages go disproportionately to white neighborhoods (Kelly; Washington-Ferguson). They saw a few hundred housing units rehabbed for lowincome residents barely make a dent in tenant demand for affordable housing in one of 
the most expensive housing markets in the United States (Bluestone and Stevenson). Eventually, the same finance executives who touted such housing partnerships called for the deregulation of mortgage finance rules in ways that abandoned public responsibility to housing all Bostonians, while helping to undermine the security of the nation's mortgage system (Securities and Exchange Commission).

Despite the gains local activists made in forcing banks and government officials to recognize the persistence of redlining and to promise reinvestment in low-income communities, then, Boston emerged from this era as one of the most unequal cities in the nation in terms of residential opportunities. Between 1980 and 1986, key years for the Boston Housing Partnership's reputation in the city, "there were only 500 units of newly constructed housing added to the neighborhood stock" of the Black community of Roxbury (Washington-Ferguson 39). Roxbury also received only 9 percent of commercial lending dollars in the city between 1981 and 1987, while other largely white communities with similar income levels received much more; East Boston, South Boston, and Charleston received 32 percent, 35 percent, and 23 percent respectively (Washington-Ferguson 48). By the late 1980s, moreover, Boston had the most expensive housing relative to wages of any of the nation's fifty largest cities. The average worker in Boston earned approximately $\$ 25,000$ per year. Though this was ten percent above the average annual wage nation-wide, it was less than half of the $\$ 60,000$ a family would need to earn to afford the median-priced home in the city, "which, at $\$ 181,200$, was approximately double the national average" (Campen 39).

The Boston Renaissance was not an egalitarian phenomenon. It took off in the midst of a turn against the viability and desirability of public governance of institutions such as schools and housing. Driven by this energy, the city would take a path that decidedly favored the interests of the finance, real estate, and technology industries, and the politicians aligned with those interests. Boston's public-private collaborations advanced a nationally-influential movement to promote a broader political agenda that included taxpayer-subsidized for-profit schools, the privatization of Social Security, deunionization, deregulation of mortgage financing, corporate-driven reform of higher education, and the assertion of state power over federal power in policymaking (Dunphy and Perkins; Hood). Through the creation of new profit centers in finance and transportation services, they created momentum for profitable reforms in primary, secondary, and higher education-all facilitated and defended by think tanks, lobbying, political contributions, and public relations campaigns. In this way, the city's corporate leaders joined what economist James K. Galbraith has called, "the predator state," or the corporate and government institutions that have systematically funneled capital into the hands of a small elite since the 1970s (131).

\section{The Bewildered}

Critics of top-down urban reform efforts did not respond with a single voice. They were part of the fragmented, yet active, US left and liberal social movements in the 1970s and 1980s (Iton; Rodgers). Many sought to shape urban reforms to promote their interests, often at great risk to themselves and their families. They challenged the centers of power and the most anti-democratic aspects of urban reform (King; Vrabel). To name just a few examples, a growing population of Black Bostonians, building on a deeply rooted African American freedom struggle, called for quality education, 
neighborhood self-determination, and equal opportunity in the workplace (Batson; Theoharis; Bundy; Miletsky). A relatively new but increasingly powerful Latino and Caribbean American movements built on the strategies of, and uneasy alliances with, the African American movement (Cruz). Various strands of the New Left protested everything from US foreign policy in Central America and South Africa to the exploitation of tenants and discrimination against gays, lesbians, the disabled, and the elderly (Larson; Vrabel). Boston saw widespread and determined grassroots movements try to tame the elitist modes of urban reform and economic development.

Some of those on the outside of power criticized not just the specifics of power politics shaping the Boston Renaissance, but the entire vision of growth-as-progress. They saw the city's revival, the rise of neoliberal Boston, as an extension of the long history of segregation, discrimination, and exploitation in the city. Fanny Howe emerged as one such critic of the disorder that had long warped the city, and that would shape the ideas and initiatives that drove the renaissance. Howe's family roots reach into early Boston history, with both slave traders and abolitionists in her family tree. She thus entered her literary career immersed in the long history of politics and culture of a city forever torn between its commonwealth origins and its entwinement with the rise of racial capitalism in the Atlantic World (Peterson).

In her autobiographical work, Howe frames her own political maturation in terms of the difficult relationship she had with her mother-a playwright and actress who spent most of her time with the literary elite of Boston-and in terms of her close relationship to her father and his three life-defining commitments: the fight against the Nazis in World War II, the excessive repression of McCarthyism, and US racism. When her father died in February 1967, "after a meeting on school busing in Roxbury, and shoveling snow," she reveals, "it was the end of safety for me" and the beginning of her own bewilderment. "After that there would be more assassinations and less grounded action except in Vietnam. And then the light would change and the orientation of energy and possibility would radically alter" (2008). The death of her father brought home to Fanny Howe the intimate meanings of the loss of idealism felt across much of the Euro-American world in the late 1960s.

In her four novels, two books of essays, and multiple short stories, Howe narrates and analyzes her life growing up in post-World War II Boston. A child of one of the city's oldest elite families, her early life was shaped by both the committed liberalism of her father, a legal historian at Harvard Law School, and her artistic mother, a lively figure in the US and European world of experimental theater. She came of age surrounded by elite liberal intellectuals and some of the most prominent artists of the time-at one point as a teenager she traveled to Paris and walked the city streets with Samuel Beckett. Yet after her father's untimely death in 1967, she renounced her connections to her wealthy Boston family, becoming an activist, marrying the African American activist and writer Carl Senna, moving to the largely African American community of Roxbury, and raising their three children, largely on her own, first in Boston and then across New England and the United States (Howe, 2003).

Howe has a way of piercing the pieties of American culture, of dramatizing the ways in which we try to make sense of the experience of being an American by ignoring, or covering over, the darker sides of US history. In one essay, Howe calls on her reader to question the ubiquity of narratives that celebrate "courage, fortitude, overcoming, and growth." She encourages us, instead, to recognize and engage narratives of survival, 
uncertainty, contingency, and interdependence. She uses her unsparing eye to describe postwar Boston as "the grave city [...] like a used, dropped newspaper that no one wanted to stoop to pick up" (2008). One of her characters says of Boston during the late twentieth century, "It was not where I wanted to be. In those days it was a drab and chaotic city, segregated by race, ethnicity, and class, with poorly educated and selfserving community leaders who invariably mishandled the funding they were given" (2008).

It was in her activism in Boston that she first learned the politics of bewilderment. She developed what she called "a domestic socialism" against the backdrop of the corporate transformation of Boston. She sustained networks made up largely of women and children organized in mutual support against the gentrification of working-class neighborhoods, the failed effort to create high-quality integrated public schools, the fumbling governance of public officials, and the ascendance of an aggressively acquisitive corporate elite. Howe worked with Jonathan Kozol and the Congress of Racial Equality (CORE) to help tenants gain rights against abusive landlords, for instance, and worked with other women, whom she called her "true colleagues," as they "formed food co-ops and community gardens [...] [took] in boarders," and helped each other find work and helped their children to find access to education (2003 23). In school choice crises, she explains, home addresses become a form of currency, or a kind of license, and they worked in secret to match children with addresses they could exchange for access schools.

21 She describes a radically child-centered politics, a politics that uses physical mobility as a tool of survival, that endures stigmatization, questions ideological certainties, and sees "certainty" itself as the kind of error that leads to violence, even war. This "domestic socialism" recognized power in being outside of the established systems of bureaucratic regimentation and other forms of violence. While they were being used as means to the end of economic growth, Howe and her colleagues sought engagement with theology, human relationships, and solidarity as ends in themselves. They did not hold out hope for a utopian end of history, but sustained a faith in radical contingency. This is the makings of the politics of bewilderment.

Howe draws upon the history she had lived to create her characters. She elevates the people, historical and fictional, "who rushed forwards and backwards within an irreconcilable set of imperatives [...] unable to handle the complexities of the world or the shock of making a difference" (2003 5-6). These are the bewildered. In each of Howe's novels, there is a character, usually a young girl, who is the victim of violence on the part of people who ought to be caring for her. The violence is disorienting, it sends the character spinning off the path of conventional social relations. It is terrible each time. These same characters, however, also evince an openness to wonder, to the "radical love" that brings at least the possibility of hope.

These are the characters for whom history most clearly emerges not as linear path, but as a spiral, a series of repetitions with a difference. "For the spiral-walker there is no plain path, no up and down, no inside or outside. But there are strange returns and recognitions and never a conclusion" (Howe, 2003 9). They embody the lives that such linear narratives tend to silence or explain away in the name of the growth of the economy or the success of the nation. As Howe explains:

The politics of bewilderment belongs only to those who have little or no access to an audience or a government. It involves circling the facts, seeing the problem from 
varying directions, showing the weaknesses from the bottom up, the conspiracies, the lies, the plans, the false rhetoric; the politics of bewilderment runs against myth, or fixing, binding, and defending. It's a politics devoted to the little and the weak; it is grassroots in that it imitates the way grass bends and springs back when it is stepped on. It won't go away but will continue asking irritating questions to which it knows all the answers. After all, the point of art-like war-is to show people that life is worth living by showing that it isn't. (2003 23)

In this Sisyphean politics, those who roll the stone up the hill seeking solidarity, mutuality, and accountability find themselves inexorably to be facing unjust forms of governance and atomized ways of living.

Whether we think of neoliberalism as a set of intertwined public policies and corporate initiatives or as a way of being, whether we think of it as caused by a rupture in response to the crisis of capital accumulation in the 1970s or as a kind of fait accompli evident in the conservatism always present in the postwar city-by the late 1980s, something recognizable as a neoliberal age was ascendant (W. Brown; Diamond; Harvey, 2011). Certainly, by the late 1980s, those with power had begun to remake the inequities of liberalism under new practices and a new name for those in the political wilderness.

Even those who have communities, then, could be bewildered, in the sense that they are being manipulated by centers of political and economic power that are becoming more and more distant from their everyday life. This is why the trajectory of inequality matters so much; in the midst of the push for "recovery" during and after the 1970s, it was becoming more and more obvious to people that the balance of power at work and in politics was becoming increasingly unequal, as both cause and effect of growing economic inequality.

Howe's project is not historical, though it makes possible a view of recent history that shows that to explain away the underside of progress is necessarily violent. Progress must be justified, because it is an ideological concept, one that shapes implicitly the attitudes and behavior of modern life, but not without erasures. The erasures are such that people suffer for real, in concrete ways. That must mean that such people are, as Howe puts it in her novel, Indivisible, "living compensations for the furious freedom of others," and that progress is not real in the sense that it is assumed to be real in our society's dominant culture (2000 479). If violence is endemic, if the order in which we live is intrinsically a violent order, then the response cannot be certainty about the future nor passivity in the present.

There is little reckoning in our times with radical doubt about the way forward, there are few public discourses willing to tell stories that are not centered on growth, progress, overcoming, and optimism. Most of us are not willing to name our shared experience of the events as "dizzying and repetitive" (Howe, 2003 18). The bewildered not only reject the notion that the way things are is how they ought to be, not only denounce the claims of those who argue with certainty about how to return society to lost glory days, not only recognize that freedom and domination are always intertwined, but also act from a position of one who understands that engagement is an end in itself. They are not lost in the sense that they have no direction to go in which to improve the state of things as they are. Reforms are possible, but any such effort at ameliorating the conditions they encounter with the people around them are either implicated in those conditions or are sustained by an active leap of faith. The action- 
radically child-centered, focused on relationships, anti-teleological-is the source of historical meaning.

Those who engaged the politics of bewilderment from a critical standpoint both countered and were implicated in the dominant trends toward privatization and the economizing of contemporary culture and identities. As such, they were not only in the minority, they had experienced what the Boston-based poet, novelist, and essayist describes as a radical "enchantment that follows a complete collapse of reference and reconcilability" caused by displacement (Howe, 2003 15). That enchantment with the possibility for something drastically different that comes from having lost one's bearings, it turns out, can allow for great flexibility in how one imagines the future.

Pushed to the political margins, the bewildered embraced their outsider status, and engaged in uncovering the dark underside of what was then called the "Boston renaissance," unveiling the myths that propped up the boosters' claims to urban rebirth. From their hard-won critical perspective, they struggled to sustain democratic modes of social organization, vernacular community planning, and radical artistic visions. In doing so they manifested dynamics that have continued to arise in conflicts over the imposition of private power over the commonwealth, including in movements such as Occupy and \#BlackLivesMatter.

\section{A People's Art of Self-defense}

We can see these contemporary resonances in the work of Dana C. Chandler, Jr. (Akin Duro), a Black Power artist, activist, civic leader, and a studio professor at Simmons College. Chandler responded to the profound violence of life in Boston in the late 1960s and 1970s by creating what he called a "people's art" that focused attention on white violence and Black Americans' everyday weapons of self-defense. Chandler also founded and ran the African American Master Artists-in-Residence Program (AAMARP), the nation's first and, at the time, only residential arts program for Black artists, at Northeastern University from 1978 to 1993, drawing diverse audiences to the exhibit spaces. He also served as the Board President for the Metropolitan Council for Educational Opportunity (METCO), Boston's voluntary metropolitan school busing program, while raising seven children with his wife in the city. Chandler persevered in the face of outright resistance from the white art world, against the racial polarization of the busing era, and in opposition to key Northeastern officials' attacks on the mission and funding of the artists' residency program in the late 1980s and early 1990 s.

Chandler framed his work in terms of the threats entailed in working both inside and outside of conventional centers of power in a world where market relations dominate, and he connected those personal experiences to the long history of European and EuroAmerican violent oppression of people of African descent. Chandler constructed images that documented white violence and counter-images of Black labor, family, and community life that articulated an original intellectual and artistic take on Black weapons of self-defense. "The reality is that one has to eat," Chandler told an interviewer in 1987, and the challenge for him as an artist, as he saw it, was to carve out institutional space in academia, in the art world, and in the polarized political world of Boston, in order to facilitate the creation of an African American "teaching art" that would "grab the viewer" and help them "find a way to move forward [...] in a 
society which places no value on black life" (Strickland 18-19). This is not a triumphant history, but a history of the tensions between necessity and tragedy in our time.

On 2 June 1967, Chandler witnessed the Boston Police viciously attack a group of fifty activists from Mothers for Adequate Welfare (MAW). After two years of petitioning and protesting for a livable welfare benefit, and demanding to be treated with dignity by caseworkers, they staged a peaceful sit-in at the Grove Hall welfare office. On the second night, the police decided the protest had to stop. Later the police would say that they had heard rumors that a social worker inside the office was suffering from a heart attack. Whatever the case may be, they rushed in. One welfare activist heard the commanding officer's order: "Now beat them. Let them have it" (Johnson). And they did. The Police came into the welfare office "wielding billy clubs and shouting 'kill 'em'" (Fuerbringer and Milbauer). One woman screamed out of the window from which the activists had been engaging passersby during the sit-in, "They're beating your black sisters in here" (Johnson). The police took the riot into the streets. "They were just mad at black people in general, you know," Chandler said (R. Brown 31). After three days of clashes, ten blocks of Boston had been ripped apart. The city's latent racial conflict had surfaced on a mass scale.

Chandler had been permanently transformed. He would never think about violence, history, or the relationship between his artwork and the larger world in the same way again. At heart, he was compelled by the realization that, in contrast to official interest in the pathologies of Black communities, the focus had to be on white violence. When, later in 1967, he was hired as a researcher for the Lemberg Center for the Study of Violence under Dr. John P. Spiegel at Brandeis University, he was asked to "research black violence." He rejected the idea. "I absolutely refused to do that," he said. "I told them that black violence was a result of white violence, so I was going to research white violence" (R. Brown 31). He and his partners, he remembered, "went into the white community and we researched white violence. So, you would find us, for instance, down on the Common when the police were beating the crap out of the hippies" (R. Brown 32). At the same time, he said, "I had the revelation that my art had to have [...] activist meaning" (Chandler, 2017). And that meaning would be defined by the necessity of self-defense-he even adopted the Yoruba name "Akin Duro," which means "Stand Up Man" or, in loose translation, "you knock me down, I'll get back up" (Capasso 173).

34 Chandler responded with the city in his mind as a wild, violent place, and his art as a set of tools of self-defense. The Grove Hall police riot marked a turning point. As he put it, "that really is when my activism as an artist began" (R. Brown 33). He explained his works in terms of their functions as weapons of self-defense. Embracing the art world gave him an escape from the violence he would have faced as an activist in the street. Becoming a full-time artist also allowed Chandler to defend himself and Black artists more broadly against being ignored by the art world. And his provocative art, he believed, could inform and empower African Americans in how to defend themselves from the constantly reinvented forms of white oppression. In his art, the intent, as he put it, would drive the content, and his intent was to promote effective self-defense in the face of incessant and ever-changing forms of white supremacist oppression. For approaching his art this way, Chandler was often dismissed, mostly by white viewers. None other than the arch-reactionary William F. Buckley articulated the view in a local television interview in Boston. "Well, of course, you understand that this is really just 
proletarian art, which really doesn't have a real meaning except as propaganda," Buckley concluded. Unsurprisingly, Chandler mocked such a view: "Once [Buckley] put it down," he said, "I knew I was painting the right stuff" (R. Brown 35).

It is impossible here to do justice to the variety of Chandler's decades of artistic works. Chandler reinvented himself as a "people's artist," showing and selling his prolific works in street shows, in local churches and community institutions, and, eventually, in his own community-facing exhibit space at Northeastern University. His work took on subjects connected to everyday life in Boston's Black communities, from the anguish caused by addiction and the violence suffered at the hands of the police to the threats of sexual violence women faced as domestic workers.

Chandler confronted his audiences with the anti-Black violence on the rise in the late 1960s and 1970s, connecting micro-level experiences in Boston to national trends. His most famous work, "Fred Hampton's Door \#2" (\#2 because the first version was stolen from the 1976 Seattle World's Fair) is a painted door with bullet holes, recalling the police assassination of Chicago Black Panther leaders Fred Hampton and Mark Clark in December 1969 (Godfrey et al.). Amongst his hardest-hitting works are also acrylic paintings that depict scenes of Klan violence and of the persistence of white supremacist hatred in US urban settings.

Chandler's "Weapons of Self-defense" series is among his most important as a view into his understanding of the violence intrinsic not just to his own moment, but to the long history of Black America. These still lifes done in acrylic, at first glance, appear to be non-conventional stylistically, but conventional in that they portray food and implements from kitchens. In Chandler's hands, however, the still life form is repurposed to force his audiences to reflect on the weapons of self-defense women had at hand to fend off their white employers who were already always would-be attackers. As Chandler put it in a 1976 caption to Salt, Pepper, Cucumbers 'n Poison, the series was "a part of my continuing effort to supply information to us about protective devices and self-defense. After all, somebody's got over 200 million civilian weapons, and it ain't us!" (Chandler, 1976).

In interview after interview, artist's statement after artist's statement, Chandler hit this point home-he was intentionally, and yes paternalistically, trying to teach women, in his own style, about the weapons of self-defense they have at hand that they might not think about. "I was saying to African American women, you need to protect yourselves, you need to know how to protect yourselves, you need to know the items that [can help] [...] but I also wanted to be using my own forms, my own colors, my own styles" (Chandler, 1976). Chandler told an interviewer, "I tried to develop an idiom," his own documentary language to describe a world that conventional understandings of history could not or would not see, or could only see as a threat. "It was Europeans who decided that it was incendiary," he reflected later (R. Brown 34).

The domestic weapons in Chandler's self-defense series communicate complex arguments about the utilitarian role of art as social lesson, and about the ability of a painting to capture-in one frame-the spiraling aspects of work and violence for Black women. For the women in his audience, Chandler meant to represent options for physical self-defense. For Chandler himself, the paintings made accessible to nearly any viewer-via the repurposing of a classical artistic form-the constantly recurring narratives of Black women forced to work in white homes and forced to protect themselves. The paintings capture how survival for Black women, and Black families, 
required risk, as they reveal the violence undergirding the "order" that is domestic labor.

For the viewer, then, the paintings portray the knowledge of a tragic historical and contemporary reality-in fact a kind of knowledge that flouts such linear notions of time-in the violence against Black women swirling through the paintings. As such, Chandler had also fashioned works of art that function as weapons in battles over the interpretation of history. They are a poison pill for anyone wanting to hold onto a sense of history defined by progress, individual agency, meritocracy, the triumph of beauty, and the overcoming of injustice. To the degree the paintings are unmoored from a particular historical moment, they force the viewer, the conscientious viewer, at least, to reckon with their own implications in cycles of violence, undermining the common desire to experience history as a movement away from past injustice. This simultaneity is horrific, presaging the kind of contemporary horror genres that white supremacist violence present, or at least immanently possible at all times (Coleman).

The prevailing ideologies of order, even conventional notions of historical time, the paintings imply, will not save us. The works attack ideas underlying a system in which progress comes precisely in ways that depend upon subordination. The paintings present a poison of self-defense that threatens the individual predator and, even more, the entire apparatus of certainty, without itself presuming to hold any certainty about an alternative utopian vision. The self-defense series-like the paintings of the Klan and white nationalists, but in a more concentrated, even more lethal way-not only open questions about the white men and women perpetrating the violence that requires the poison in the first place, but also about the possibility of making the reproductive labor at the heart of these paintings fully valued, embodied, or even sustainable without the threat to the security of everyone involved in the domestic sphere. There is a suppressed wish for, but no real vision of, a different kitchen in which the poison would be unnecessary, in which new questions would open about how to act in the space created for recognition of the incompleteness and interdependence of us all.

It is impossible to miss the less-than-utopian vision of the paintings. Of course, at the most obvious level, the paintings suggest the persistence of violence. At the same time, there is the conspicuous irony in Chandler's self-defense series that the women who are to be the subjects of the implied narrative remain disembodied. How do we explain this? Chandler assumes that Black women would not know what kinds of weapons of self-defense were available in the kitchen. He acts and speaks as though he is the agent of educating African American women. Chandler knew that African American women have had a long history of self-defense. "Self-protection is a very ancient process for African American women. In the Old South during slavery [...] and even up to the 1960s, that was very true" (Chandler, 2011). Yet there is an intrinsic pedagogical aspect to the paintings, and, as we have seen, it was an aspect Chandler readily claimed as his intention. Chandler assumes the place of authority-the teacher, the protector, the giver of power.

To complicate the point a bit, we must ask ourselves whom else Chandler is seeking to teach a lesson. Chandler explained, "I deal very seldom with specific people," meaning he was attempting to create something more emblematic of widely shared experiences (Chandler, 1976). So the people missing from the paintings were implicitly, yet obviously, part of the relationship as observers. Perhaps the most provocative aspect of the paintings, then, especially at that time, was that Chandler was teaching a lesson to 
the white men and women who, in the world the paintings forced them to confront, had to own their own part in a history of subjecting Black women to violence and thereby imposing an inherently fragile, violent order. Members of the white audienceperhaps even viewing the paintings standing next to Black observers-had to face the reality that their violence had long been met by the righteous violence of Black women. For the audience, the paintings become a reminder that it was Black women just offstage in the kitchen who were the actors in this history, just as it was the Mothers for Adequate Welfare who permanently transformed Chandler's thinking, who got this history moving in the first place.

The images compel the viewer to look for the disembodied-to move forward into our own lives with a different lens. This is an opening, then, not only to see African American women as agents of self-defense against physical attackers, but also to confront the possibility of imagining a conceptual framework outside of the one in which our society remains bounded. It is possible, in the moral universe that Chandler has constructed, that agents of self-defense can become what some theorists have called agents of "holy terror," a kind of terror in which hope resides (Eagleton). The paintings hold the possibility that violence will break through and bring to life an otherwise latent potential to overturn the injustices that dominate the present order.

Chandler's paintings beg the question about how people continually confronted the rise and remaking of a rationalized, capitalistic Boston, dependent upon racist, patriarchal, misogynistic violence of many kinds. His paintings provide ammunition against those who would suggest that African American women's domestic labor, and domestic spaces themselves, were not important. They work against those who sustain the dangerous myth, which originated in the moment that African American women entered white families' kitchens, that the kitchen was a paternalistic space where the happily subservient maid became "like family" to her owner or employer. This is what Cedric J. Robinson called, "the utilization of the political to defend ourselves from the destructive objectivation of the myth; the apparatuses of repression and control" (214). Chandler sets out to create in-your-face, instructive images for self-defense. Here are the tools, he is saying, be ready to use them when you need them-and you will need them.

Beyond recovering the agency of women or rescuing them from historical anonymity, then, there is the added conceptual insight that the women we are compelled to consider by their absence from these paintings challenged the kind of authority that sought to use them as objects of greed and desire. They challenged the authority of employers, policymakers, caseworkers, the police, and the hostile public, calling into question the kind of authority that assumed the naturalness of inequality as a determination of power relations. Thus, they prompt us to go further conceptually to suggest that in their collective response to systemic violence, they challenged the entire ideological construct of leadership and authority undergirding the existing political system.

Chandler's still lifes emerge, however problematically, as appeals to empathy. Perhaps despite Chandler himself, who remains tied to certain forms of patriarchal authority, they can be read as inspirations "to define order and responsibility," as Robinson put it, "in terms of the indivisibility of things." There is a possibility to see in these paintings not just the guilt that we must attribute to the violent attackers in the kitchen, but also our own shame at failing to act on our interdependence. In his own incomplete way, 
then, Chandler inspires a reconstitution of "the will and the need to remain one with all" (Robinson 202).

\section{Challenging the Terms of Order}

Howe and Chandler, of course, were far from alone in their question of the dominant trends around them in the late 1960s and 1970s. Indeed, it is helpful to consider their dissenting work in view of how others interpreted that conjuncture. The work of historian Sam Bass Warner, Jr., and political scientist Cedric J. Robinson both echoes and helps to clarify where Howe and Chandler fit into larger streams of thought regarding urban political economy in the 1970s.

Warner opened his 1972 book, The Urban Wilderness, with an indictment of US urban history. "The giant cities of our country," Warner began, "have always seemed to me, as they have to most Americans, vast incomprehensible places [...]. I have lived with a pervasive sense of existing as a dweller in small clearings in the midst of an urban wilderness" (3). This was the hard-won perspective of an activist-scholar. As he put it in a 1974 interview, "the unfolding of capitalism [...] in this urban situation [is] disastrous." In cities long defined by "the large and growing middle class" shaping the city "to its own benefit," the question was now whether large-scale public and private institutions could stem the power of property owners to dominate urban life (Stave 96). In Warner's view, the obsession with private property was the core problem of US urban history.

50 To change the troubling course of urban development in the 1970s, Warner argued, Americans would have to divorce themselves from the traditional middle-class ideal of cities as places where everyone would be their own business proprietor and homeowner. "The American city is the inhumane place it is," he argued, "because we cling to the formulations of the seventeenth century and the myths of a society of small proprietors." Reformers inevitably failed to foster egalitarian change when they failed to disrupt "our tradition of land law and land management" (Warner 18). The US obsession with the rights and welfare of private property owners gave the nation's cities their wild nature. "Like neurotic middle-aged patients, our cities are case histories of the repercussions of basic flaws and conflicts" (Warner 3). Only greater democratic power would allow citizens to resist "private property's social, economic, and political tyrannies" (Warner 133). Greater access to democratic power would allow local people to transform their cities from a persistent state of wild incomprehensibility into legible, humane spaces where open competition could be balanced against the need for innovation and requirements of strong communities.

In the early 1970s, then, as remarkable as it may seem in retrospect, Warner believed there was hope for horizontal democratic models of political power and economic growth. He contended that democratic planning could control the municipal government and "socialized" large-scale corporations would allow citizens to overwhelm the traditional power, and values, of the middle class. Warner prompted his readers to reject the wholesale privatization of power over the city. "We stand at a moment of unique opportunity," he declared, when organized mass pressure could compel large-scale corporations to serve the public interest. The opportunity, however, would be short-lived. "If we fail to socialize soon we will have lost, through foolish devotion to our cherished myth of private property, a historic opportunity to gain [...] 
democratic control of the building of our society" (Warner 133). As Warner saw this moment of opportunity pass, he came to believe that the greatest obstacle was not ignorance, but the refusal to change. "Many of the destructive, indeed self-destructive, aspects of our human settlement," Warner said in a 1977 lecture, "come not from iron necessities, but from our unwillingness to confront what we as a society know about ourselves" (xIx). To Warner, this meant confronting the city as a wilderness.

Writing his PhD dissertation in the 1970s, the iconoclastic political scientist Cedric J. Robinson went further to argue that our entire understanding of politics and leadership as a system of order is, itself, an ideological formation. So controversial that Robinson's doctoral committee refused to consider the dissertation because they could not comprehend it within the standards of the field in the 1970s, Robinson eventually won his degree and published The Terms of Order: Political Science and the Myth of Leadership in 1980. At the end of a decade of political chaos, Robinson declared that, for all the evidence of injustice and disorder characterizing our modern politics, we tend to "persist in the delusion that, beneath the chaos, ordered systems reign administered by stable political institutions and fundamentally resilient cultural and economic integrations" (Robinson XxIX). Robinson goes far beyond debating which political party ought to hold power or whether Liberal or Marxian theories of politics hold more potential for justice. Bourgeois and radical traditions are, from this perspective, both within the political order. Even European anarchist traditions, Robinson argues, amount to political refutations of the political order.

What all of these expressions of "politicality as ideology" have in common is that they are obsessed with inequality (Robinson 23). Therefore, all modes of the political seek to redress or conserve inequality, as the case may be, by instituting leadership that can either win authority by some form of agreement, or take it by force, and thereby command the power to determine the shape of "order." Power is essential to order, but power is always suspect. The history of the modern world "order," Robinson is arguing, is a history of colonization, slavery, and evolving forms of imperialism. Structural disorder and violence continue to define our times, rather than "crises" that could be resolved within the existing political order. "As such, the existential experience of the individual is denied by resorting to a heritage as citizen of a politically maintained social order rationalized by the authority of leadership. Greater social cohesion, we are instructed, is dependent upon better leadership" (Robinson xxIX). Yet, from Robinson's perspective, those who study conventional forms of leadership remain stuck examining not the solution to, but the cause of, social problems. Conceived in this way, the study of political science is self-referential, and ordinary understandings of politics and leaderships verge on paradoxical. If Robinson is right, existing modes of leadership, authority, and political struggles lead only to the extension of their historical effectsnot cohesion but disorder. To do that is to remain confined within an ideological framework that is itself the cause of the chaos in the city.

of course, from a historical, rather than a theoretical perspective, there is no impermeable line between power politics and the desire to create something beyond the existing forms of politics. This is why self-defined radical urban scholars such as Henri Lefebvre, David Harvey (2013), Don Mitchell, and, more recently, Michael Sorkin, have called attention to "the right to the city" as a vision of democratic struggle over the power to determine the order of everyday life. Sociologist Erik Olin Wright, moreover, has argued that anti-capitalists can resist capitalism in four ways. 
Anticapitalists may seek to "smash" the system through revolution; "tame" the system through governance; escape the system; and build and defend spaces where commonwealth values and institutions flourish in ways that "erode" capitalism's hold on everyday life. Those who resisted the privatization of the commonwealth in Boston created a rich, if fragmented history in which their forays into formal power politics intertwined with the work of imagining alternatives to the political relations that impinged on their very ability to make a living in the city.

This tension between struggling with the order of the city as it was and the recognition that the city, in fact, remained very much a wild place in the midst of its ostensible renaissance, together created the experience of bewilderment and the impulse to imagine some new order for urban life. Like those seeking to survive in a hostile wilderness, while trying to shape a grove of their own, they were always, as Howe put it, "rushing forwards and backwards within an irreconcilable set of imperatives" (Howe, 2003 5-6).

\section{A Non-teleological Bewilderment}

Boston in the 1970s was an urban wilderness, a town starkly divided, where order was inextricable from chaos and politics came to resemble war. Racial and ethnic polarization nearly tore the city of closed neighborhoods apart, even as academics, politicians, and corporate leaders sought to preserve their elite status against a myriad of fragmented local challenges. Seeking to establish a new order in this old, declining, chaotic city, elite Bostonians acted on an ambiguous mix of paternalism and reaction to build a vision of the city in which solutions to the crises of capitalism and democracy could be resolved through socially responsible public-private partnerships. In doing so, they both helped create a new center for American urban governance, and simultaneously expelled many of the most creative Bostonians into the political wilderness.

57 For American culture, this last phrase-in the wilderness-carries a heavy weight of associations. As the United States has been, and remains, a deeply religious nation, many Americans would think of the Israelites, whom God allowed to flee bondage and to survive and purify themselves through the trials of the wilderness in preparation for the Promised Land. Or they might think of Jesus fasting for forty days and forty nights in the wilderness, resisting the devil's temptations to forsake his God. Such religious connotations have from the outset been intertwined with secular understandings of what many Americans have thought of as their mission to settle and improve the New World and, eventually, the world as a whole. Americans-stretching from the Puritan migrants of the 1600 s through the Western migrants of the nineteenth century to the liberal nationalist proponents of American empire since the late nineteenth centuryhave proudly claimed God's blessing for their taking of land, labor, and life from the "savages" of the globe.

In each of these three versions of bewilderment-the Jewish story of the Exodus, the Christian gospels, what we might call the American Bible of growth-the disorientation, confusion, and sufferings in the wilderness were necessarily temporary and had a higher historical purpose. The Israelites and Jesus may have suffered a significantly greater sense of doubt about their place in the world than the Americans, but in the end, at least in retrospect-or to those with a direct connection to God's word-the 
suffering in the wilderness served its purpose: the making of history. They are the classic teleological stories-whatever troubles may have been suffered could be explained by the goal of the story, the saving of the Israelites, the rise of the savior for all Christians, or the growth of the United States as an engine of global liberty and progress.

The politics of bewilderment as it is used here shares with each of these narratives a sense that disorientation, confusion, being without a clear path, realizing the freedom to question progress, being in the wilderness are essential to understanding history. But the concept employed here is based on an understanding of bewilderment that is anti-teleological and, in fact, directly confronts the way Americans have used narratives of growth and progress in order to explain away and justify the obvious and growing economic and political disparities in the United States in the last fifty years.

As people with little or no formal power-especially in Boston's African American, Latino, and queer communities, but also some in the white working class-struggled for access to opportunity, they confronted a popular discourse that denied there was a basis for their grievances or even that they deserved a voice in the public debate. Pushed to the political margins, some embraced their outsider status, arguing in diverse ways that solutions to the city's dilemmas required not just better technocratic leadership, but a recognition that the city as it was could not offer a path to life as it ought to be.

61 Their work did not amount to a model we can find in the past to make the future better in any straightforward or linear kind of way. This ambiguous history matters not just because working people's histories have intrinsic worth, though that is true, but also because the people who worked with, accommodated to, sought to manipulate, and imagined alternatives to the prevailing direction of the city's politics and economic development left an important record of resistance to the emerging "terms of order," both as cultural figures and activists. In these stories, we find historical illustrations of key alternative ideas about the past being worked out provisionally and, again, not "successfully" in the sense that we have not seen a "break" since 1968 in the direction that someone like Robinson would like to see. But the working out of ideas is important. The politics of bewilderment is not all of political history that we would like to remember and preserve for future generations. But it is so stigmatized, so devalued, so repressed, even as it holds so much potential value, that it is worth particular attention.

62 The politics of bewilderment depends on the recognition that the next formations, and the ways they might be built, are still unknown, especially in the face of attempts to explain what must happen next. Howe's notion of bewilderment will be familiar, and strange, to those who appreciate the power of disillusionment and alienation in everyday modern life. The politics of bewilderment points to narratives of those who have struggled to sustain democratic modes of social organization, vernacular community planning, and radical artistic visions in the face of an increasingly restricted political and social imagination. The bewildered did not find a path out of their political wilderness, but they engaged in the work demanded to sustain families and communities of various shapes-confronting the future envisioned by powerful institutions and individuals-toward a different fate that could not be foreseen, through a process that could not be planned ahead of time. There are attempts to 
explain what must happen, but though they tend to be logically sound, practically they come off as fantasies. For Hardt and Negri:

Smashing the state means destroying the gap [between rulers and the ruled] and thus creating political and administrative institutions that immanently organize the collective, democratic decision-making of the entire population. The question for today's machinic subjectivities, then, so full of knowledge and intelligence, is how they can invent democratic practices and administrative institutions that organize effectively the life of the multitude. (Hardt and Negri 134).

Perhaps this is what must happen, though saying so remains a declaration on the outside of power. Even more, such a call must turn attention to those who have long been crying out in the urban wilderness.

\section{BIBLIOGRAPHY}

BATSON, Ruth. The Black Educational Movement in Boston: A Sequence of Historical Events, A Chronology. Boston: Northeastern University. 2001.

BLUESTONE, Barry, and Mary Huff STEVENSON. The Boston Renaissance: Race, Space, and Economic Change in an American Metropolis. New York: Russell Sage Foundation, 2002.

BROWN, Robert. "Dana Chandler Interview.” Smithsonian Archives of American Art, 11 March-5 May 1993.

BROWN, Wendy. Undoing the Demos: Neoliberalism's Stealth Revolution. New York: Zone Books, 2017. BUNDY, Tess. “'Revolutions Happen through Young People!': The Black Student Movement in the Boston Public Schools, 1968-1971." Journal of Urban History, vol. 43, no. 2, 2017, p. 273-293.

CAMPEN, James T. “The Struggle for Community Investment in Boston, 1989-1991.” From Redlining to Reinvestment: Community Responses to Urban Disinvestment. Ed. Gregory D. Squires. Philadelphia: Temple University Press, 1992, p. 38-72.

CAPASSO, Nicholas. “Expressionism: Boston's Claim to Fame.” Painting in Boston: 1950-2000.

Eds. Rachel Rosenfield Lafo, Nicholas Capasso, and Jennifer Uhrhane. Boston: DeCordova Museum and Sculpture Park, 2002.

hymanbloominfo.org/expressionism-bostons-claim-fame/13/.

Accessed 19 January 2021.

CHANDLER, Dahna. “Chandler's Art, The People's Art: 1967-Present, Part 1.” 23 December 2011. blogtalkradio.com/theakinduro/2011/12/23/chandlers-art-the-peoples-art-1967-present-part-1. Accessed 23 March 2018.

CHANDLER, Dana C., Jr. "Sketchy Life History.” Box 1, Folder 1. "Biographical Information, 1976." Dana C. Chandler, Jr. (Akin Duro) Papers, 1973-1991. Simmons College Special Collections.

CHANDLER, Dana C., Jr. “A Globally Renowned Outsider Artist.” Facebook Post on 21 October 2017.

facebook.com/danacchandlerjr/.

Accessed 25 March 2018. 
COLEMAN, Robin R. Means. "We're in a Golden Age of Black Horror Films." The Conversation, 29 May 2019.

theconversation.com/were-in-a-golden-age-of-black-horror-films-116648.

Accessed 18 September 2020.

CONNOLLY, N.D.B. “A White Story.” Dissent Magazine, 22 January 2018.

dissentmagazine.org/blog/neoliberalism-forum-ndb-connolly.

Accessed 19 January 2021.

CRONIN, Joseph Marr. Reforming Boston Schools, 1930 to the Present: Overcoming Corruption and Racial Segregation. New York: Palgrave Macmillan, 2008.

CRUZ, Tatiana M.F. “'We Took 'Em On': The Latino Movement for Educational Justice in Boston, 1965-1980." Journal of Urban History, vol. 43, no. 2, 2017, p. 235-255.

DIAMOND, Andrew. Chicago on the Make: Power and Inequality in a Modern City. Berkeley: University of California Press, 2017.

DUNPHY, Paul, and Mark Umi PERKINS. "The Pioneer Institute: Privatizing the Common Wealth." Political Research Associates, 13 July 2002.

politicalresearch.org/2002/07/13/pioneer-institute-privatizing-common-wealth.

Accessed 5 April 2018.

EAGLETON, Terry. Holy Terror. New York: Oxford University Press, 2005.

FARRAR, Eleanor. The Boston Compact: A Teaching Case. Boston: Center for Policy Research in Education, 1988.

FARRAR, Eleanor, and Anthony CIPOLLONE. The Business Community and School Reform: The Boston Compact at Five Years. Boston: National Center on Effective Secondary Schools, 1998.

FUERBRINGER, Jonathan, and Marvin E. MILBAUER, "Roxbury, Quiet in Past, Finally Breaks into Riot; Why Did Violence Occur?" The Harvard Crimson, 15 June 1967.

thecrimson.com/article/1967/6/15/roxbury-quiet-in-past-finally-breaks/.

Accessed 4 May 2018.

GALBRAITH, James K. The Predator State: How Conservatives Abandoned the Free Market and Why Liberals Should Too. New York: Free Press, 2014.

GODFREY, Mark, Zoé WHITLEY, TATE MODERN, CRYSTAL BRIDGES MUSEUM OF AMERICAN ART, and BROOKLYN MUSEUM, eds. Soul of a Nation: Art in the Age of Black Power. New York: Distributed Art Publishers, 2017.

GROGAN, Paul. "Introduction.” The Good City: Writers Explore 21 $1^{\text {st }}$ Century Boston. Eds. Emily Hiestand and Ande Zellman. Boston: Beacon Press, 2004, p. 1-11.

HARDT, Michael, and Antonio Negri. Assembly. New York: Oxford University Press, 2017.

HARVEY, David. A Brief History of Neoliberalism. 2005. Oxford: Oxford University Press, 2011.

HARVEY, David. Rebel Cities: From the Right to the City to the Urban Revolution. London: Verso, 2013.

HOOD, John. "How the States Turned Right.” The National Review, 18 September 2015.

web.archive.org/save/https://www.nationalreview.com/2015/09/republican-dominance-stateshow-it-happened/.

Archived 20 September 2019.

HOWE, Fanny. Indivisible. Cambridge, MA: Semiotext(e), 2000. 
HOWE, Fanny. The Wedding Dress: Meditations on Word and Life. Berkeley: University of California Press, 2003.

HOWE, Fanny. “My Father Was White but Not Quite.” Poetry Magazine, 1 December 2008. poetryfoundation.org/poetrymagazine/articles/69163/my-father-was-white-but-not-quite. Accessed 8 August 2015.

CROZIER, Michel, Samuel P. HUNTINGTON, and Joji WATANUKI. The Crisis of Democracy: Report on the Governability of Democracies to the Trilateral Commission. New York: New York University Press, 1975.

ITON, Richard. In Search of the Black Fantastic: Politics and Popular Culture in the Post-Civil Rights Era. Oxford: Oxford University Press, 2010.

JOHNSON, Akila. “The Forgotten Riot that Sparked Boston's Racial Unrest.” The Boston Globe, 2 June 2017, bostonglobe.com/metro/2017/06/01/the-forgotten-protest-that-sparked-city-racial-unrest/ Ory39137z87TwdBfrqUnTP/story.html.

Accessed 7 July 2017.

KELLY, Hope. “Discrimination in Lending.” Boston TV News Digital Library. WGBH, 29 September 1989.

bostonlocaltv.org/catalog/V_BOGAVVPY2HTZBW6.

Accessed 15 September 2018.

KING, Mel. Chain of Change: Struggles for Black Community Development. Boston: Hugs Press, 2016.

LARSON, Eric D. “Anticolonial Anti-Intervention: Puerto Rican Independentismo and the US ‘Anti-Intervention' Left in Reagan-Era Boston.” Journal of Transnational American Studies, vol. 9, no. 1,2018 , p. 93-118.

LEFEBVRE, Henri. "The Right to the City." 1968. Writing on Cities. Edited and translated from the French by Eleonore Kofman and Elizabeth Lebas. Oxford: Blackwell, 1996, p. 63-181.

MILETSKY, Zebulon Vance. “Before Busing: Boston's Long Movement for Civil Rights and the Legacy of Jim Crow in the 'Cradle of Liberty'." Journal of Urban History, vol. 43, no. 2, 2017, p. 204-217.

MITCHELL, Don. The Right to the City: Social Justice and the Fight for Public Space. New York: The Guilford Press, 2003.

MOYNIHAN, Daniel Patrick. Letter to Harvard President Derek Bok, 5 May 1972. Folder 7, “Bok, Derek C., 1968, 1971-1972, and Undated.” Moynihan Papers, Part I, Section 145. Library of Congress.

PETERSON, Mark. The City-State of Boston: The Rise and Fall of an Atlantic Power, 1630-1865. Princeton: Princeton University Press, 2019.

PORTZ, John. "External Actors and the Boston Public Schools: The Courts, the Business Community, and the Mayor." Wilson Center, no. 12, July 2011.

wilsoncenter.org/publication/external-actors-and-the-boston-public-schools-the-courts-thebusiness-community-and-the.

Accessed 1 October 2020.

ROBINSON, Cedric J. The Terms of Order: Political Science and the Myth of Leadership. 1980. Chapel Hill: The University of North Carolina Press, 2016.

RODGERS, Daniel T. Age of Fracture. Cambridge, MA: Harvard University Press, 2012. 
SCHNEIDER, Jack. Excellence for All: How a New Breed of Reformers Is Transforming America's Public Schools. Nashville: Vanderbilt University Press, 2011.

SECURITIES AND EXCHANGE COMMISSION. "Press Release: SEC Charges State Street for Misleading Investors About Subprime Mortgage Investments.” 4 February 2010. web.archive.org/save/https://www.sec.gov/news/press/2010/2010-21.htm. Archived 22 September 2019.

SORKIN, Michael. What Goes Up: The Right and Wrongs to the City. New York: Verso, 2018.

STAVE, Bruce M. “A Conversation with Sam Bass Warner, Jr.” Journal of Urban History, vol. 1, no. 1, 1974, p. 85-110.

STRICKLAND, Edward. "Interview with Dana C. Chandler." Dana Chandler Retrospective 1967-1987: The More Things Change, the More They Remain the Same. Let My People Go! North Hall Gallery, Massachusetts College of Art, March, 1987. Eds. Dana Chandler and Massachusetts College of Art. Boston: The College, 1987, p. 6-8, 10, 12-14, 18-21, 24-27.

THEOHARIS, Jeanne. “'I'd Rather Go to School in the South': How Boston's School Desegregation Complicates the Civil Rights Paradigm." Freedom North: Black Freedom Struggles Outside the South, 1940-1960. Eds. Jeanne Theoharis, Matthew Countryman, and Komozi Woodard. New York: Palgrave Macmillan, 2003, p. 125-151.

VON HOFFMAN, Alexander. House By House, Block By Block: The Rebirth of America's Urban Neighborhoods. New York: Oxford University Press, 2003.

VRABEL, Jim. A People's History of the New Boston. Amherst: University of Massachusetts Press, 2014.

WARNER, Sam Bass, Jr. The Urban Wilderness: A History of the American City. 1972. Berkeley: The University of California Press, 1995.

WASHINGTON-FERGUSON, Frances. "Developing Real Estate in Roxbury: Are the Constraints Greater than the Opportunities for Black Development Firms?" Thesis, Massachusetts Institute of Technology, 1990.

dspace.mit.edu/handle/1721.1/70637.

Accessed 28 August 2018

WRIGHT, Erik Olin. "How to Be an Anticapitalist Today.” Jacobin, 2 December 2015. jacobinmag.com/2015/12/erik-olin-wright-real-utopias-anticapitalism-democracy/. Accessed 5 May 2019.

\section{NOTES}

1. In the book project related to this research, I uncover the histories of Bostonians who joined in what, in retrospect, might be seen as anti-neoliberal activism. They include the diverse, militant activists who organized a school bus drivers' union in the midst of the 1970s busing crisis, and who won battles against the multinational corporations and city officials who worked to destroy their union. They include those housing activists who forced city, state, and federal officials to recognize the city's history of redlining and exploitative home financing, and then worked against private solutions to those problems. They include parents who volunteered, seeking to ensure the implementation of school desegregation in a way that would be best for the city's children as a whole. And they include a characteristically Bostonian world of intellectuals who 
sought to challenge the ideas behind the rise of an anti-democratic, anti-egalitarian culture they called by many different names.

\section{ABSTRACTS}

Suffering both chronic decline and an acute social and economic crisis in the 1960s and 1970s, Boston's corporate leaders began to create the initiatives that would allow the city to emerge in the succeeding decades as a leader amongst the nation's newly thriving technology- and professional-service-based urban economies. At the same time, the city's top-down reformers began creating new inequalities and new forms of exploitation. They also built on what has been called a "neoliberal rationality" that, in part, sought to create profit centers and market-oriented ways of living in everything from public schools, public universities, and public infrastructure to residential housing and artistic culture. This essay focuses on the work of two Bostonians in particular-writer and activist Fanny Howe and Black Power artist and activist Dana C. Chandler, Jr. (Akin Duro)-who imagined and sought to create alternative futures for Boston beginning in the late 1960s. Their work challenged not just the fact of deep inequality at the outset of an age of economic growth, but also the very terms of order that infused dominant notions of political and economic thinking. What Howe has described as "the politics of bewilderment," or what Chandler conceived of as a people's art of survival in response to an intrinsically violent city, provide an alternative way to approach late-twentieth-century Boston from the perspective of those who experienced it as more an urban wilderness than a renaissance city.

Dans les années 1960 et 1970, alors que la ville de Boston connaît une grave crise économique et sociale et apparaît en déclin, des hommes d'affaires se mobilisent pour lancer un certain nombre d'initiatives qui permettront à la ville de s'imposer comme le chef de file d'une renaissance urbaine fondée sur les nouvelles technologies et les services professionnels. Au même moment, les décideurs, qui imposent des réformes d'en haut, sont à l'origine de nouvelles formes d'inégalités et d'exploitation. Ces derniers s'inspirent d'une «rationalité néolibérale » qui cherche notamment à mettre en compétition et à tirer profit de tout un ensemble d'infrastructures publiques, des écoles aux universités, mais aussi du logement et de la culture. Cet article porte sur le travail de deux habitants de Boston en particulier - l'écrivaine et militante Fanny Howe et l'artiste et militant du Black Power Dana C. Chandler, Jr. (Akin Duro) - qui, à partir de la fin des années 1960, ont imaginé et cherché à créer des visions alternatives de l'avenir de Boston. Leur travail ne visait pas seulement à remettre en question les inégalités profondes qu'ils observaient à l'aube d'une période de forte croissance économique, mais aussi les termes mêmes de l'ordre politique et économique dominant. Ce que Howe décrivait comme une «politique de la stupéfaction » (politics of bewilderment) et ce que Chandler concevait comme une sorte d'art populaire de la survie déployé en réponse à la violence intrinsèque de la ville permettent d'approcher d'une autre manière le Boston de la fin $\mathrm{du} \mathrm{xx}^{\mathrm{e}}$ siècle ; plutôt qu'une ville en pleine renaissance, ces pratiques nous permettent de voir Boston sous la forme d'un espace sauvage (wilderness) urbain. 
INDEX

Keywords: Boston (Massachusetts), Chandler Jr. (Dana C.) (Akin Duro), Black Arts Movement, bewilderment, Howe (Fanny), neoliberalism, terms of order, urban history, urban wilderness Mots-clés: Boston (Massachusetts), Chandler Jr. (Dana C.) (Akin Duro), Black Arts Movement, stupéfaction, Howe (Fanny), néolibéralisme, termes de l'ordre, histoire urbaine, espace sauvage urbain (urban wilderness)

\section{AUTHOR}

JEFFREY HELGESON

Texas State University 